International Journal of Linguistics, Literature and Translation

ISSN: 2617-0299 (Online); ISSN: 2708-0099 (Print)

DOI: $10.32996 / \mathrm{ijllt}$

Journal Homepage: www.al-kindipublisher.com/index.php/ijllt

\title{
A Semantic Perspective on Referring Expressions of Paradise and Hell in the Holy Quran: The Case of Chapter 30 (Amma part)
}

\author{
Mervat Isa Albufalasa 8 (D) $\square$ \\ Assistant Professor, Department of English Language and Literature, College of Arts, University of Bahrain \\ $\triangle$ Corresponding Author: Mervat Isa Albufalasa, E-mail: malbuflasa@uob.edu.bh
}

\section{ARTICLE INFORMATION}

Received: February 04, 2021

Accepted: March 12, 2021

Volume: 4

Issue: 3

DOI: $10.32996 /$ ijllt.2021.4.3.10

\section{KEYWORDS}

Semantics, Referring expressions, Holy Qur'an, Paradise, Hell

\section{ABSTRACT}

The present study attempts to examine the referring expressions in Chapter 30 (Amma part) of the Holy Qur'an. It aims at identifying the referring expressions of Paradise and Hell involved in Amma part in particular. The study also attempts to investigate which of the two entities (Paradise and Hell) of the referring expressions have been referred to more. The study implements quantitative and qualitative methods to classify and analyse the referring expressions. In order to classify and describe the referring expressions, a content analysis checklist is utilized to categorize the referring expressions. The findings of the study reveal that there are 54 referring expressions of Paradise and Hell in Amma part, where 35 referring expressions refer to Hell representing 65\%, and 19 referring expressions refer to Paradise representing $35 \%$. The findings reveal that the referring expressions of Paradise and Hell contribute significantly to persuading people to follow the teaching of Islam in order to go to Paradise and dissuading them from rejecting them, ending up in Hell.

\section{Introduction ${ }^{1}$}

The Holy Qur'an is the eternal book revealed to Prophet Mohammed, peace be upon him (PBUH), which is considered to be his everlasting miracle. It is characterised by its noble meanings and strength of statements. Dr. Bilal Philips defined it as the word "Qur'an," a verbal noun, is equivalent in meaning to "qiraa'ah," as both come from the verb "qara'a" which means "to read." That is, Qur'an literally means "a reading or reciting". However, the term "Qur'an" has been historically used specifically to refer to the book which was revealed to Prophet Muhammad (PBUH). The Qur'an could be defined as Allah's words which were revealed in Arabic in a rhythmical form to Prophet Muhammad (PBUH). Its recitation is used in acts of worship and its smallest Chapter (Surah) is of a miraculous nature.

Qur'anic expressions set a great example of linguistic creativity. The power of linguistic structures and the embedded meanings involved in Quran have amazed Arabs who have complete mastery over their language. As a result, they have conducted much research to study Qur'anic structures in an attempt to unravel its mystery. Among the expressions that are included in the Holy Qur'an, the referring expressions of Paradise and Hell which have received a multitude of names, descriptions and expressions where Allah rewards believers with Paradise in the Day of Judgment and warns disbelievers of their impending punishment in Hell.

Paradise is "described in the Qur'an as an eternal afterlife of peace and bliss, where the faithful and righteous are rewarded. They will be restful in the presence of God, in "gardens beneath which rivers flow." Jannah comes from an Arabic word which means "to cover or hide something". On the other hand, Hell is defined as a real place prepared by God for those who do not believe in Him, rebel against His laws, and reject His messengers. Hell is an actual place, not a mere state of mind or a spiritual entity. The horrors, pain, anguish, and punishment are all real, but different in nature than their earthly counterparts. Hell is the ultimate humiliation and loss, and nothing is worse than it: "Our Lord! Surely, whom You admit to the Fire, indeed You have disgraced him, and never will the wrongdoers find any helpers." (Qur'an 3:192).

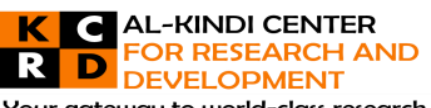

Your gateway to world-class research

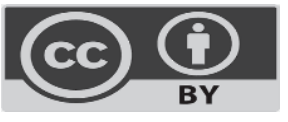

Published by Al-Kindi Center for Research and Development. Copyright (c) the author(s). This open access article is distributed under a Creative Commons Attribution (CC-BY) 4.0 license 
Through Semantics, the systematic study of meaning (Kreidler, 2014), which is a field of linguistics, some denotations and connotations of the Holy Qur'an have been explored through studying the referring expressions of Paradise and Hell in Chapter 30 (Amma part). Referring expressions and referents are defined as "a piece of language, a noun phrase, that is used in an utterance and linked to something outside language, some living or dead or imaginary entity or concept or group of entities or concepts. That 'something' is the referent, not necessarily physical nor necessarily 'real'" (Kreidler, 2014, p. 130).

The Holy Qur'an is a miracle that proves the credibility of the message of the Prophet Muhammad (PBUH). It has been sent to a community known for its fluency and eloquence of literature and poetry. However, Allah Almighty challenged them to create only a verse like it, but they couldn't. Thus, the Holy Qur'an has high language structures and sublime meanings. This paper attempts to shed light on these meanings and analyze them from a semantic perspective to recognize the miracle of the Lord's word and understand its meanings through the study of referring expressions of Paradise and Hell in Chapter 30 (Amma part) of the Holy Qur'an. In addition, this study attempts to find out to which two entities the referring expressions refer more by statistic analysis and a consultation of a specialist in Islamic sciences to know the reason for that.

The present study aims to contribute to spreading the meanings of the Holy Qur'an through applying some of the concepts that have already been studied. Furthermore, there is a dearth of English research investigating the referring expressions of Paradise and Hell in the Holy Qur'an from a semantic perspective. The expressions in Chapter 30 (Amma part) of the Holy Qur'an that refer to Paradise and Hell have not been collected and discussed from a semantic perspective. Therefore, the study at hand attempts to explore these expressions.

\section{Literature Review}

The concept of reference is seen as a process that encompasses participants' interpretation and production of referring expressions in a particular context (Denis, 2010). Reference determines the relationship of some constituents; a particular word or a phrase and an object or an abstract, and that referring expressions are determined on a spectrum from highly informative noun phrases, and indefinite and definite noun phrases, to low informative forms (Graf and Davies, 2014). These expressions are defined as linguistic expressions, and reference determines the relation between the use of these linguistic expressions and what they stand for or denote (Sullivan, 2012). In his study, Sullivan (2012) argues that language plays a central role in tracing the states and doings of people, events or phenomena, and thus, referring expressions are fundamental in that they could be interpreted from the semantics-pragmatics interface. Sullivan highlights that reference has 'a two-pace semantic relation' and that referring expressions have a semantic role in signaling out a particular referent. It is also argued that referring is a pragmatic act as "the rules of language and of society synergize in determining meaning, intended as a socially recognized object sensitive to social expectations about the situation in which the utterance to be interpreted is embedded" (Capone, 2005: 1357).

Referring expressions have been studied from different perspectives; philosophical, psychological, semantic, computational linguistics, corpus linguistics and functional. Semanticians have identified referents and assigned meaning to expressions as Hurford et al. (2007) and Kreidler (2014) have discussed that these linguistic expressions, mostly noun phrases, are used to refer to a specific individual or object with a particular referent in mind, and they are used to identify an entity. This identification relies on the context in which language is exchanged as these expressions are semantically crucial in identifying the propositions conveyed in particular contexts (Lyons, 1981). In a study conducted by Ball (2010), the researcher has presented an extension for Jackendoff's Conceptual Semantics about the different types of referring expressions which can be used in referring to types, models, groups, situations and examples. The results of this study lie on exploring the origin of the referring categories and the difference between the situation model and mental model. In addition to this, the study claimed that there is no direct reference for the realistic objects in the external world.

From the Systemic Functional Grammar's perspective, Fontaine (2007, p. 159) has investigated referring expressions in relation to "their realisation in text in terms of their function and form" as Systemic Functional Linguistics considers language as systemic and functional. It is systemic in terms any language offers a system of choices for language users choose where each choice is important for the realisation of meaning (Halliday, 2009). It is functional in terms of how people use language as a means to express meanings in certain situations, and the forms they choose from language are influenced by the social and cultural contexts in which they exchange meanings (Coffin et al., 2013; Eggins, 2013 ; Hasan, 2009).

In another study, Fontaine (2006) has investigated the place of referring expressions in Systemic Functional Linguistics. In this study, the researcher aims to determine the position of referring expressions in the systemic functional linguistics, where the study proposes that there is a change in the perspective from nominal and structural referring expressions to the functional reference which has low attention in the systematic functional linguistics. The result is that the main difficulty is they are linked directly with the cognitive process, where the referent looks like an explanation or cognitive representation and mental construction. 
Pepp (2009) has attempted to address a basic question of what semantic reference is, where the notion has the role in semantics in the natural language. She argues that there are two ways towards conceiving semantic reference, which presents different starting points to answer this question. The two conceptions are the conventional conception of semantic reference which she considers the standard conception, and she proposes another one: the historical conception of semantic reference. She has commented on the state of historical conception as a main perspective about the semantic reference more viable than the conventional conception for the semantics of natural language. In addition, she argues that the historical conception could be seen as a basic view about semantic reference that establishes the ground for developing of a theory of semantic reference.

Moreover, Runge (2006) casts light on pragmatic effects of semantically redundant anchoring expressions in biblical Hebrew narratives. He proposes that the referring expressions are used greatly and regularly in the Biblical and Hebrew narratives where the objective relation is constructed correctly. The study determines the hypothetical relation of the referring expressions. The result was that the referring expressions are used greatly and confirmed in the contexts in a realistic way for achieving the objective implications.

In addition, Zulaica-Hernández and Gutiérrez-Rexach (2011) have dealt with the information status of antecedents and compared the referential properties of demonstratives and personal pronouns in Spanish discourse. They have discerned the difference between using referring expressions on the basis of the cognitive or information state of the antecedents. Thus, it is proposed that the sample referring expressions are using the personal pronouns greatly whereas it prohibits the use of demonstratives. The result is that the difference between these referring expressions is that demonstratives are participating actively in the cognitive structure through referring to the main subject or the changes in the sub-subjects whereas the speakers are using the neuter personal pronouns for referring to the established subjects.

Bach (2004) has conducted a study on referring expressions in the headlines of newspapers. She has explored the use of referring expressions in the homepages of eight American newspapers presented in the sections of art, sport, business, and news. She has investigated the referring expressions in the headlines for all of these sections in two English newspapers in China. The results have shown that the American newspapers are using intermediate accessibility markers more than high and low accessibility markers. In spite of this, they are making the headlines as short as possible through using zeros or making them rather long through using unlimited figures or descriptions. Moreover, these newspapers use last names many times more than other kinds of names in the headlines or American newspapers on the Internet. Moreover, the rest of the sections (except news section) and newspapers use medium accessibility markers often rather than the low and high ones. News section uses a large amount of low accessibility markers instead of medium and high ones. Business and commerce sections are using the large amounts of zeros whereas the sport section uses the large amount of last names and the art section uses the first names and the news section uses unlimited descriptions. The English newspapers in china, at the counter of the American ones there, are using low accessibility markers more than medium and high ones. The English newspapers rarely use the zeros and pronouns.

Downey (2010) has conducted a study on child acquisition of referring expressions. This study has explored how the children at the age of three, four, or five years use the referring expressions in different educational tasks according to the situational semantic model. The study compares the children's use of referring expressions in contextualized and decontextualized tasks. The results have demonstrated explanations about the referring expressions and their structure and use in linguistic examples and texts. In addition, this study has presented evidence on the effects of changeable context and how it is matching with age. More insights have been given from varied perspectives: syntactic, semantic and pragmatic.

In the same vein, Gundel, Dimitris and Kowalsky (2004) have explored children's use of referring expressions in relation to the Theory of Mind. In their study, they have presented the results of basic analyzing tests for children's use of referring expressions and their implications related with the theory of mind. The study has concluded that the children are using complete group of the types of referring expressions (the definite and indefinite articles, personal pronouns, demonstratives) in a proper way in the age of three or earlier.

Wicklund (2012) has also examined the use of referring expressions by autistic children and how this disability affects their use of referring expressions in conversations. This study compares the referring expressions used by the autistic children and the normal expressions at the same age. The results show that there is a correlation between the impairment representation and autism to affect the cognitive and procedural aspects in irregular context where many researchers suggest that it is better to notice how autistic children deal with the presented realistic challenges in everyday life. Furthermore, the result has demonstrated that the autistic children failed in determining the information about the cognitive state and the conceptual content which the listener needs. 
Finally, Lam (2012) has focused on his thesis on the relation between the efficacy of linguistic pronunciation and the prominence of referring expressions. The study has underlined the importance of the implications of the effectiveness of lingual prominence at the linguistic standards and delivering the lingual message. The results have shown that the factors of the linguistic standards of message and other factors of linguistic levels affect prominence in different ways, where the factors of linguistic levels led to differences in the period of speaking whereas the factors of the message have been obvious through the different languages.

The current study aims to investigate the referring expressions of Paradise and Hell in Chapter 30 (Amma part) of the Holy Qur'an. It draws upon the "Translation of the Meaning of the Noble Qur'an in the English Language" by Dr. Muhammad Taqi-udDin Al-Hilali and Dr. Muhammad Muhsin Khan, Arabic and English texts. Moreover, the study aims to explore the obvious referring expressions which describe Paradise and Hell themselves in the "Translation of the Meaning of the Noble Qur'an in the English Language" and has avoided any referring expressions which do not describe Paradise and Hell themselves such as Paradise's and Hell's people. The study posits two main research questions. They are as follows:

1. What are Referring expressions that refer to Paradise and Hell in Chapter 30 (Amma part) of the Holy Qur'an?

2. To which of the two entities (Paradise and Hell) of the referring expressions refer more?

\section{Methodology}

This section introduces the methodological steps that are employed in the research which involve research design, samples, instruments, data collection, data analysis and statistical tools.

\subsection{Research Design}

This study employs qualitative and quantitative methodological approach. The qualitative method has been utilized because the data are in the form of verses that have been analyzed based on the referring expression and the referent concept. The purpose behind this is to find out the referring expressions that referred to each Paradise and Hell to answer the first research question. The study also implements a quantitative method to provide statistical answers to the second research question in this study and that was related to which of the two entities: Paradise and Hell, of the referring expressions have been referred to more.

\subsection{Data Analysis}

The data have been analyzed following a number of procedures. First of all, after having the complete data of referring expressions that have been collected from Amma part, the researcher has categorized them into two classes: referring expressions of Paradise and referring expressions of Hell, that have been in the form of words, phrases or sentences. After finishing categorizing these classes, the data have been interpreted from each category based on the referring expressions and referent concept. Then, the researcher has investigated which of the two entities: Paradise or Hell, of the referring expressions have been referred to more statistically. Finally, the researcher gives concluding remarks and recommendations on the result of analysis.

\subsection{Corpus}

This study employs a corpus-based approach in that it has collected its data from the Holy Qur'an; more specifically, Amma part that comprises of 37 Surahs which is Chapter 30 and the last Chapter of the Holy Qur'an. These Surahs are: An-Naba, AnNaazi'aat, Abasa, At-Takwir, Al-Infitaar,Al-Mutaffifin, Al-Inshiqaq, Al-Burooj, At-Taariq, Al-A'laa, Al-Ghaashiyah, Al-Fajr, Al-Balad, Ash-Shams, Al-Lail, Ad-Duhaa, Ash-Sharh, At-Tin, Al-Alaq, Al-Qadr, Al-Bayyina, Az-Zalzala, Al-Aadiyaat, Al-Qaari'a, At-Takaathur, Al-Asr, Al-Humaza, Al-Fil, Quraish, Al-Maa'un, Al-Kawthar, Al-Kaafiroon, An-Nasr, Al-Masad, Al-lkhlaas, Al-Falaq and Al-Naas.

\subsection{Instruments}

In order to classify and describe the referring expressions of Paradise and Hell in Amma part, this study employs a content analysis checklist categorizing these referring expressions involved in the Surahs of Amma part in The Translation of the Meaning of the Noble Qur'an in the English Language by Dr. Muhammad Taqi-ud-Din Al-Hilali and Dr. Muhammad Muhsin Khan Arabic and English texts. The researcher has compiled this checklist based on the referring expressions and referent concept. This study employs the linguistic meanings as a textual analytic tool, probing implied meanings in order to identify the referring expressions of Paradise and Hell that appeared in Amma part. In addition, the researcher examines to which of the referent, paradise or hell, the referring expressions refer more by using the statistical analysis program. The Statistical tools used in this study have been appropriate to the research question and outline. The main data analysis techniques used in the research are frequency count and percentage applying the statistical program.

\section{Findings and Discussion}

This study attempts to answer two research questions that revolve around identifying the referring expressions that are used in Chapter 30 (Amma part) of the Holy Qur'an that refer to Paradise and Hell, and to which of the two entities (Paradise and Hell) 
these referring expressions refer to more frequently. The findings of this study are presented according to the Surah name and the referring expressions found to Paradise and Hell in each Surah. The referring expressions for Paradise and hell are presented in Tables 1 and 2 respectively.

Table 1. The referring expressions of Paradise

\begin{tabular}{cccc} 
No. & Surah name & Frequency & Percentage \\
\hline 1 & An-Naba & 3 & $15.7 \%$ \\
2 & An-Naazi'aat & 1 & $5.2 \%$ \\
3 & At-Takwir & 1 & $5.2 \%$ \\
4 & AL-Infitaar & 1 & $5.2 \%$ \\
5 & Al-Mutaffifin & 1 & $5.2 \%$ \\
6 & Al-Burooj & 1 & $5.2 \%$ \\
7 & Al-Ghaashiya & 7 & $27 \%$ \\
8 & Al-Fajr & 1 & $5.2 \%$ \\
9 & At-Tin & 1 & $5.2 \%$ \\
10 & Al-Bayyina & 1 & $5.2 \%$ \\
11 & Al-Qaari'a & 1 & $5.2 \%$ \\
\hline & Total & $\mathbf{1 9}$ & $\mathbf{3 5} \%$ \\
\hline
\end{tabular}

Table 1 above shows the Surahs and the frequency and percentages of the referring expressions to Paradise. These referring expressions are found in 11 Surahs, with a total of 19 referring expressions. Among the 19 referring expressions of Paradise, $36.8 \%$ of these expressions are found in Surah Al-Ghaashiya, $15.7 \%$ is found in Surah An-Naba, and $5.2 \%$ is found in the rest of the Surahs as mentioned in the table.

Table 2. The referring expressions of Hell

\begin{tabular}{cccc}
\hline No. & Surah name & Frequency & Percentage \\
\hline 1 & An-Naba & 4 & $11.4 \%$ \\
2 & An-Naazi'aat & 1 & $2.8 \%$ \\
3 & At-Takwir & 1 & $2.8 \%$ \\
4 & AL-Infitar & 1 & $2.8 \%$ \\
5 & Al-Mutaffifin & 1 & $2.8 \%$ \\
6 & Al-Inshiqaaq & 2 & $5.7 \%$ \\
7 & Al-Burooj & 3 & $8.57 \%$ \\
8 & Al-A'laa & 2 & $5.7 \%$ \\
9 & Al-Ghaashiya & 1 & $2.8 \%$ \\
10 & Al-Fajr & 1 & $2.8 \%$ \\
11 & Al-Balad & 1 & $2.8 \%$ \\
12 & Al-Lail & 3 & $8.57 \%$ \\
13 & At-Tin & 1 & $2.8 \%$ \\
14 & Al-Bayyina & 1 & $2.8 \%$ \\
15 & Al-Qaari'a & 3 & $8.57 \%$ \\
16 & At-Takaathur & 2 & $5.7 \%$ \\
17 & Al-Humaza & 6 & $17 \%$ \\
18 & Masad & 1 & $2.8 \%$ \\
\hline & Total & $\mathbf{3 5}$ & $\mathbf{6 5 \%}$ \\
\hline
\end{tabular}


Table 2 above demonstrates the Surahs and the frequency and percentages of the referring expressions to Hell. These referring expressions have been found in 18 Surahs, with a total of 35 referring expressions. Among the (35) referring expressions of Hell, $17 \%$ of these expressions are found in Surah Al-Humaza, 11.4\% in Surah An-Naba, 8.57\% in Surah Al-Burooj, Surah Al-Lail and Surah Al-Qaari'a, 5.7\% in Surah Al-Inshiqaaq, Surah Al-A'laa and Surah At-Takaathur, and 2.8\% in the rest of the Surahs indicated in the table.

The referring expressions of Paradise and Hell in Amma part are compared as shown in Figure 1 below.

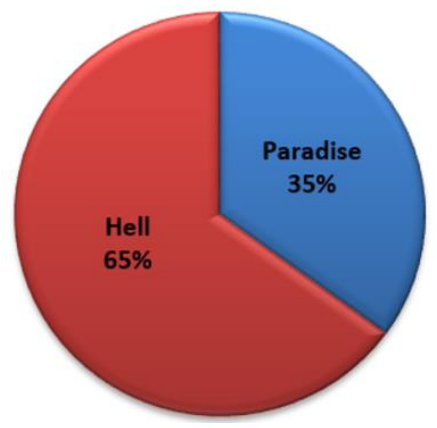

Fig 1. The referring expressions of Paradise and Hell in Amma part

Figure 1 draws on a comparison between the referring of expressions of Paradise and Hell, indicating that $65 \%$ of the expressions refers to Hell while 35\% refers to Paradise in Amma part. The number of referring expressions, Paradise or Hell, is variant from one Surah to another. Based on the statistics above, there are 54 referring expressions of Paradise and Hell that can be distinguished in Amma part. These expressions are categorized based on what the referent is.

The findings are discussed below in relation to the research questions posited by this study. In addition, conclusions and recommendations are addressed afterwards.

\subsection{Discussion of Research Question 1}

The first research question aims to identify the referring expressions of Paradise and Hell in Chapter 30 (Amma part) and their frequencies in the different Surahs. Based on the research results, it can be said that there are many referring expressions of Paradise and Hell in Amma part. There are 11 Surahs that include 19 referring expressions of Paradise which are as follows: AnNaba, An-Naazi'aat, At-Takwir, AL-Infitar, Al-Mutaffifin, Al-Burooj, Al-Ghaashiya, Al-Fajr, At-Tin and Al-Bayyina and Al-Qaari'a. There are many direct references of Paradise in some of the aforementioned Surahs, such as in the following examples:

\section{Al-Bayyina (The Evidence) 8 verses, Madina}

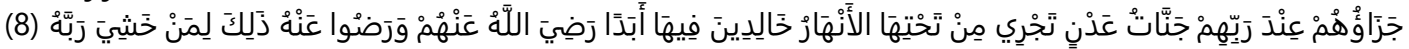

8. Their reward with their Lord is Adn (Eden) Paradise (Gardens of Eternity), underneath which rivers flow. They will abide therein forever, Allah will be pleased with them, and they with Him. That is for him who fears his Lord.

\section{Al-Ghaashiya (The Overwhelming) 26 verses, Mecca}

فِي جَنَّةٍ عَالِيَِة (10)

10. In a lofty Paradise.

لَا تَسْمَعُ فِيها لاغِيَةً (11)

11. Where they shall neither hear harmful speech nor falsehood.

فِيهَا عَيْنْ جَارِ يَةٌُْ (12)

12. Therein will be a running spring.

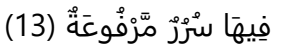

13. Therein will be thrones raised high.

\section{Al-Burooj (The Constellations) 22 verses, Mecca}

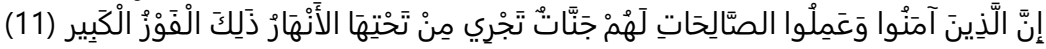

11. Verily, those who believe and do righteous good deeds, for them will be Gardens (Paradise) under which rivers flow. That is the great success. 


\section{At-Takwir (The Overthrowing) 29 verses, Mecca}

وَإِذَا الْجَنَّةُ أُْْلِفَتْ (13)

13. And When Paradise is brought near

\section{Al-Fajr (The Dawn) 30 verses, Mecca}

وَادْخْلي جَتَّتِي (30)

30. And enter you My Paradise

An-Naba (The Announcement) 40 verses, Mecca

لاّ يَسْمَعُونَ فِيهَا لَغْوَا وَلا كِذَّابًا (35)

35. No Laghw (dirty, false, evil talk) shall they hear therein, nor lying.

\section{An-Naaziaat (Those who drag forth), 46 verses, Mecca}

فَإِنَّ الْجَنَّةَ هِيَ الْمَأُوَى (41)

41. Verily, Paradise will be his abode.

The above-mentioned examples show that all the referring expressions of the referent Paradise are noun phrases such as in Examples 10 (Al-Ghaashiya), 11 (Al-Burooj), 13 (At-Takwir), 30 (Al-Fajr ) and 41 (An-Naaziaat). Other referring experessions are in the plural form such as in Examples 8 (Al-Bayyina) and 11 (Al-Burooj). Pronouns are also found such as in examples 11,12 and 13 in Surah Al-Ghaashiya and example 35 in Surah An-Naba. The examples also exhibit positive correlations between the referent (Paradise) and other referring expressions, such as in Surah An-Naaziaat in which Paradise is compared to shelter; Surah AlBurooj and Surahs Al-Bayyina in which Paradise is associated with Gardens of eternity and great success; and Al-Ghaashiya Surah where Paradise is seen as something lofty. These references to Paradise entail metaphorical descriptions in which metaphors and visual imageries are utilized to describe Paradise vividly.

In other Surahs, there are indirect references to Paradise that include many co-referential expressions. These expressions are synonyms of Paradise as well as other expressions that are metaphorically related to Paradise, such as in the examples below:

\section{An-Naba (The Announcement) 40 verses, Mecca}

إنَّ لِلْمُتَّقِينَ مَفَازًا (31)

31. Verily, for the Muttaqûn, there will be a success (Paradise);

حَدَائقِ وَأَعْنَابًا (32)

32. Gardens and grape yards;

\section{AL-Infitaar (The Cleaving) 19 verses, Mecca}

إنَّ الأَبْرَارَ لَفِي نَعِيمٍ (13)

13. Verily, the Abrar (the pious believers of Islamic Monotheism) will be in Delight (Paradise);

\section{Al-Mutaffifin (Defrauding) 36 verses, Mecca}

إنَّ الأَبْرَارَ لَفِي نَعِيمٍ (22)

22. Verily, Al-Abrar (the pious believers of Islamic Monotheism) will be in Delight (Paradise).

\section{Al-Inshiqaaq (The Splitting Open) 25 verses, Mecca}

إِلا الَّذِينَ آمَنُوا وَعَمِلْوا الصَّاِلِحَاتِ لَهُمْ أَجْرْ غَيْرُ مَمْنُونِ (25)

25. Save those who believe and do righteous good deeds, for them is a reward that will never come to an end (i.e. Paradise)

\section{Al-Ghaashiya (The Overwhelming) verses, Mecca}

لا تَسْمَعْ فِيهَا لاغِيَةً (11)

11. Where they shall neither hear harmful speech nor falsehood.

فيها عين جارية (12)

12. Therein will be a running spring.

فِيها سُرْرْ مَرْفْوعَةُ (13)

13. Therein will be thrones raised high.

وَأَكْوَابْ مَوْضُوَْةُ (14)

14. And cups set at hand.

وَنَمَارِقُ مَصْفُوفَةُ (15)

15. And cushions set in rows. 
(16)

16. And rich carpets (all) spread out.

\section{At-Tin (The Fig) 8 verses, Mecca}

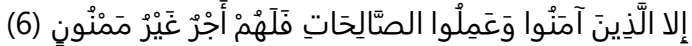

6. Save those who believe (in Islamic Monotheism) and do righteous deeds, then they shall have a reward without end (Paradise).

In the afore-mentioned Surahs, Paradise is described using vivid images, and those images are used as the referring expressions of Paradise. In Surah Al-Ghaashiya, for example, the referring expressions of paradise is used more frequently than the other Surahs, and as with other Surahs, Paradise is connotatively associated with success, gardens of grapes, running springs, delight, endless rewards, high thrones, rich carpets spread out, and where harmful speech nor falsehood are not heard. Other expressions can be considered as synonyms of Paradise such as success, delight, and endless reward.

On the other hand, there are 18 Surahs that contain 35 referring expressions of Hell in Amma part: An-Naba, An-Naazi'aat, AtTakwir, AL-Infitar, Al-Mutaffifin, Al-Inshiqaaq, Al-Burooj, Al-A'laa, Al-Ghaashiya, Al-Fajr, Al-Balad, Al-Lail, Al-Bayyina, Al-Qaari'a, At-Takathur, Al-Humaza and Al-Masad. The referent Hell is directly referred to as in the examples below, which are all considered noun phrases:

\section{An-Naba (The Announcement) 40 verses, Mecca}

إنَّ جَهَنَّمَ كَانَتْ مِرْصَادَا (21)

21. Truly, Hell is a place of ambush

An-Naaziaat (Those who drag forth), 46 verses, Mecca

وَبِّْرَتِ الْجَحِيمُ لِمَنْ يَرَى (36)

36. And Hell-fire shall be made apparent in full view for (every) one who sees,

\section{At-Takwir (The Overthrowing) 29 verses, Mecca}

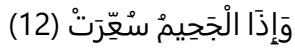

12. And when Hell-fire is set ablaze.

\section{AL-Infitaar (The Cleaving) 19 verses, Mecca}

وَإِنَّ الْفُجَّارَ لَفِي جَحِيمِ (14)

14. And verily, the Fuijar (the wicked, disbelievers, polytheists, sinners and evil-doers) will be in Hell.

\section{Al-Mutaffifin (Defrauding) 36 verses, Mecca}

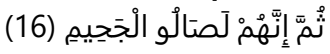

16. Then, verily, they will indeed enter (and taste) the burning flame of Hell.

\section{Al-Burooj (The Constellations) 22 verses, Mecca}

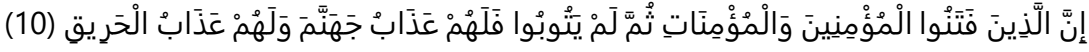

10. Verily, those who put into trial the believing men and believing women (by torturing them and burning them), and then do not turn in repentance (to Allah), then they will have the torment of Hell, and they will have punishment of the burning Fire.

\section{Al-Fajr (The Dawn) 30 verses, Mecca}

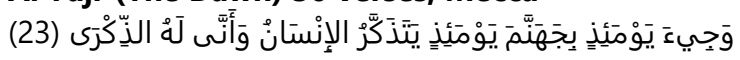

23. And Hell will be brought near that Day. On that Day will man remember, but how will that remembrance (then) avail him?

\section{At-Takathur (Competition) 8 verses, Mecca}

(6) لَتَرََّْْ الْجَحِيمَ (6)

6. Verily, You shall see Hell.

\section{Al-Bayyina (The Evidence) 8 verses, Madina}

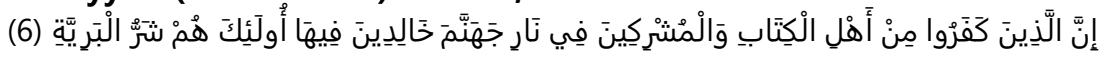

6. Verily, those who disbelieve (in the religion of Islam, the Qur'an and Prophet Muhammad (Peace be Upon Him) from among the people of the Scripture (Jews and Christians) and Al-Mushrikun will abide in the Fire of Hell. They are the worst of creatures.

Hell as a referent is connotatively associated with referring expressions that can be related to the conceptual metaphor of fire which is related to the blazing fire, the crushing fire and the burning fire as in the examples below: 


\title{
At-Takwir (The Overthrowing) 29 verses, Mecca
}

وَإِذَا الْجَحِيمٌ سُعِرَتْ

12. And when Hell-fire is set ablaze.

\section{Al-A'laa (The Most High) 19 verses, Mecca}

الَّذِي يَصْلَى النَّارَ الْكُبْرَى (12)

12. Who will enter the great Fire (and will be made to taste its burning)

Al-Lail (The Night) 21 verses, Mecca

أَنْذَرْتُكُمْ نَارَا تَلَظَّى

14. Therefore I have warned you of a Fire blazing fiercely (Hell);

\author{
Al-Qaari'a (The Calamity) 11 verses, Mecca \\ نَارْ حَامِيَةُ (11) \\ 11. (It is) a fiercely blazing Fire.
}

Other referring expressions of Hell is associated with a dwelling place, boiling water, taste imagery and painful torment as in the following examples:

An-Naba (The Announcement) 40 verses, Mecca

لِلََّاغِينَ مَآَبًا (22)

22. A dwelling place for the Taghoon (those who transgress the boundary limits set by Allah like polytheists, disbelievers in the Oneness of Allah, hypocrites, sinners, criminals), A dwelling place for the Taghoon is the referring expressions of the Hell.

إلا حَمِيمًا وَغَسَّاقًا (25)

25. Except boiling water, and dirty wound discharges

فذوقوا فلن نزيدكم إلا عذاباً (30)

30. So taste you (the results of your evil actions). No increase shall We give you, expect in torment.

\section{Al-Inshiqaaq (The Splitting Open) 25 verses, Mecca}

فبشرهم بعذاب أليم (24)

24. So announce to them a painful torment.

Paradise and Hell are considered the referents of the aforementioned referring expressions according to "referring expressions and referent" concept. The variety of referring expressions that refer to Paradise and Hell encourage people to do good deeds to enter Paradise, and discourage people from doing bad deeds that will land them in Hell. Runge (2006), in his study of the pragmatic effects of semantically redundant anchoring expressions in biblical Hebrew Narrative, argues that the referring expressions are used greatly and regularly in the Biblical and Hebrew narratives. In such narratives, the objective relation is constructed appropriately and that the referring expressions are used significantly and confirmed in the contexts for achieving the objective implications. The results of this study are in line with that of Runge (2006) in that the repeated ocuurences of the referring expressions are used to achieve the aims of encouraging and/or warning people. The results also confirm that those expressions are mostly noun phrases as discussed by Hurford et al. (2007) and Kreidler (2014). They highlight that the referring expressions of Paradise and Hell are linguistic expressions which included mostly noun phrases that indentified particular entities, and these identifications rely on the context in which the language is used, and that these expressions entail semantic propositions conveyed in a particular context (Lyons, 1981).

\subsection{Discussion of Research Question 1}

The second research question investigates the extent to which of the two referents (Paradise and Hell) of the referring expressions refer to more. According to the research findings, there are 19 referring expressions that refer to Paradise in 11 Surahs Amma part. These referring expressions of Paradise represent 35\% of the referring expressions of Paradise and Hell. AlGhaashiya is the highest Surah containing the referring expressions of Paradise, where it represents $27 \%$ as indicated in Table 1. On the other hand, there are 35 referring expressions that refer to the Hell in 18 Surahs in Amma part. The referring expressions of Hell represent $65 \%$ of all referring expressions of Paradise and Hell. Al-Humaza is the highest Surah that includes the referring expressions of Hell, where it represents $17 \%$ as indicated in Table 2. Consequently, the referring expressions of Hell are more referred to than the referring expressions of Paradise in Amma part. The findings of this study show that the referring expressions of Paradise and Hell are raised in some Surahs and lowered in others in Amma part. This is line with Bach (2004) study in which they have investigated the referring Eexpressions in the headlines of newspapers and come up with the fact that 
that there are many ways of using referring expressions which emphasize the fact that there are different expressions raising in some cases and lowering in other cases.

The findings of this study highlight the significance of language in tracing the states and doings of people as stated by Sullivan (2012) and that referring expressions of Paradise and Hell have a semantic role to signal out a particular referent. Based on the aforementioned examples of the referring expressions of Paradise and Hell, it is noticed that these co-referential expressions are related closely to people's states and doings, and how their deeds determine their lives after death. In addition, the findings depict the contemplation that these referring expressions have a pragmatic role in determining meaning and sending out particular messages that meet the social expectations based on the interpretation of the people of a particular society (Capone, 2005). This also goes in line with the perspective of the Systemic Functional Linguistics, where the interpretation of a text depends on both the form and function in a particular context (Fontaine, 2006). Based on the results of this study, the interpretation of the two referents, Paradise and Hell, depends on the mental constructions of such referents and that, in the Islamic world, Muslims are expected to meet the expectations of their societies in that they have to obey Allah and do good deeds in order to be rewarded, and if they fail to do so then, they will be punished as shown in the warning language used in the above Surahs.

The person, who contemplates in Qur'an, can find that the verbal inimitability is clear especially in the significations and contexts of verses. The Holy Qur'an is full of promises, intimidations, determinations, and statements. If people contemplate about the significance of Surahs of Amma part and its subjects, they will find the part of promise, intimidation, the citation of Paradise and Hell, and the way of addressing the speech to human and the subject of invitation and intimidation. The thinker finds that Allah mentions Hell in many verses more than paradise, and perhaps it is because Allah is talking to human beings who are supposed, in their life, to be aware of the consequences of doing ill deeds and be warned not to end up in Hell. The believer in life looks like the bird, its pinions are fear and hope, but the side of fear is dominated in life and the side of hope is dominated in dying and life after death. The person will not become a complete believer unless he gathers between fear and hope. Moreover, mentioning the horrors of Day of Resurrection, the punishment of disbelievers; paradise for believers; the situation of past nations and how Allah has punished them because of their oppression, is considered a wake-up call to mankind.

\section{Conclusion}

From a semantic perspective, the present study is based on analysis of the text content, where the referring expressions of Paradise and Hell have been analyzed in a manner similar to Bach (2004) and Runge (2006) as their studies have been based on analysis of the text content. The current study examines the referring expressions in Chapter 30 (Amma part) of the Holy Qur'an. It identifies the referring expressions of Paradise and Hell involved in the different Surahs in Amma part. This study demonstrates that Hell has been the predominant of the studied part because Allah is talking to human beings who are supposed, in their life, to be afraid more than hopeful until the very end were they should be more hopeful. A content analysis checklist categorizing the referring expressions was used. The findings are 54 referring expressions of Paradise and Hell in Amma part, where there are 35 referring expressions refer to Hell, representing $65 \%$, and there are 19 referring expressions related to Paradise, representing $35 \%$. The linguistic experssions that are found are mainly noun phrases, including nouns, pronouns and in both forms, singular and plural. The referring expressions of both Paradise and Hell undoubtedly contribute to persuading people to do good deeds that will land them in Paradise and dissuading them from doing bad deeds that will land them in Hell.

The study also recommends that more research should be done on referring expressions of Paradise and Hell on the other parts of the Holy Qur'an that are not included in this study. In addition, other expressions should be studied because of the paramount importance of the Holy Qur'an to the life of Muslims to increase the literature and studies related to Holy Qur'an. Finally, other linguisctic perspectives can be utilized such as psychological, computational, pragmatic, corpus linguistics, cognitive and functional to futher explore other interesting outcomes.

\section{References}

[1] Bach, K. (2004). Thought and reference. Clarendon Press.

[2] Ball, J. (2010). Simplifying the mapping from referring expression to referent in a conceptual semantics of reference. In Proceedings of the Annual Meeting of the Cognitive Science Society (Vol. 32, No. 32).

[3] Capone, A. (2005). Pragmemes (a study with reference to English and Italian). Journal of Pragmatics, 37(9), 1355-1371.

[4] Coffin, C., Donohue, J., \& North, S. (2013). Exploring English grammar: From formal to functional. Routledge.

[5] Denis, A. (2010). Generating referring expressions with reference domain theory. In 2010 Proceedings of the 6th International Natural Language Generation Conference, (pp. 27-35).

[6] Downey, C. (2010). Child acquisition of referring expressions. Louisiana State University.

[7] Eggins, S. (2013). An introduction to systemic functional linguistics. Continuum.

[8] Fontaine, L. (2007). The variability of referring expressions: An alternative perspective on the noun phrase in English. In The LACUS forum (Vol. 33, pp. 159-170). 
[9] Fontaine, L. (2006). The place of referring expressions in Systemic Functional Linguistics. Cardiff University.

[10] Graf, E., \& Davies, C. (2014). The production and comprehension of referring expressions. Pragmatic development in first language acquisition, 10, 161.

[11] Gundel, J., Ntelitheos, D., \& Kowalsky, M. (2007). Children's use of referring expressions: some implications for theory of mind. ZAS Papers in Linguistics, 48, 1-21.

[12] Halliday, M. (2009). Methods-techniques-problems. Continuum companion to systemic functional linguistics, 59-86.

[13] Hasan, R., \& Webster, J. J. (2009). Semantic variation: Meaning in society and in sociolinguistics. Equinox.

[14] Hurford, J., Heasley, B., \& Smith, M. B. (2007). Semantics: A coursebook. Cambridge University Press.

[15] Kreidler, C. (2014). Introducing English semantics. Routledge.

[16] Lam, T. (2012). The prominence of referring expressions: Message and lexical level effects Doctoral dissertation University of Illinois at Urbana-Champaign.

[17] Lyons, J. (1981). Language and linguistics. Cambridge university press.

[18] Pepp, J. (2009). Semantic Reference not by Convention? Abstracta, 5(2), 116-125.

[19] Runge, S. (2006). Pragmatic effects of semantically redundant anchoring expressions in Biblical Hebrew narrative. Journal of Northwest Semitic Languages, 32(2), 85-102.

[20] Sullivan, A. (2012). Referring in discourse. Cambridge Handbook of Pragmatics.

[21] Wicklund, M. (2012). Use of referring expressions by autistic children in spontaneous conversations: Does impaired metarepresentational ability affect reference production?

[22] Zulaica-Hernández, I., \& Gutiérrez-Rexach, J. (2011). On the Information Status of Antecedents: Referring Expressions Compared. Bochumer Linguistische Arbeitsberichte, 173. 